\title{
Technical project of complex fast cycle heat treatment of hydrogenous coal preparation
}

\author{
V.A. Moiseev ${ }^{1}$, V.G. Andrienko ${ }^{1}$, V.G. Pileckij ${ }^{1}$, A.I. Urvancev ${ }^{1}$, \\ D.V. Gvozdjakov², V.E. Gubin², A.S. Matveev², L.V. Savostyanova ${ }^{2}$ \\ ${ }^{1}$ Closed joint-stock company «KOMPOMASh-TJeK», Moscow \\ ${ }^{2}$ Tomsk Polytechnic university, Tomsk
}

Annotation. Problems of heat-treated milled hydrogenous coal preparation site creation in leading fast cycle heat treatment complex were considered. Conditions for effective use of electrostatic methods of heat-treated milled hydrogenous coal preparation were set. Technical project of heat treatment of milled hydrogenous coal preparation site was developed including coupling of working equipment complex on fast heat treatment and experimental samples of equipment being designed for manufacturing. It was stated that methods of electrical separation are used for heat-treated milled hydrogenous coal preparation with effective ways of organic and mineral components separation. Laboratory test for determination of optimal separation size sent into separators of heat-treated milled hydrogenous coal were made.

\section{Problem setting and its solution}

Rational use of natural resources and effective use of energy are two main requirements of Guideline №2008/1/EC of European Parliament and Council of the European Union 'About complex prevention and pollution control.' It is known [1-5] that technologies of hydrogen coal preliminary drying and heat-treated hydrogen coal preparation enables improvement of energy efficiency of enterprises up to $5 \%$ of each accordingly. Long experience of heat and power complex objects operation activity allows for the conclusion that creation of a new piece of equipment is needed for heat-treated hydrogen coal preparation together with electric separators of high capacity [4-10]. Results of research on heat-treated milled hydrogen coal preparation of brand $1 \mathrm{~B}, 2 \mathrm{~B}$ and $3 \mathrm{~B}$ are the reason for this.

The suggested technical project of hydrogen coal preparation site involves coupling of working equipment complex on fast heat treatment and experimental samples of equipment being designed for manufacturing. Research processes of effective organic fuel preparation being analyzed is accompanied by such stages as electrostatic separation, interworking of electric and mechanical forces evaluation acting in a housing area of a separator etc. [57].

It was formerly stated that coarseness classification is recommended at separation on drum separators as centrifugal force on unsorted material, which values are proportional to cube of particle diameter, can neutralize activity of electric forces proportional to square of particle diameter [5, 8-12].

When developing engineering design process of hydrogen coal particles separation of semiconductors from dielectrics with coronal electrostatic way of drum type was made as the most effective one. The results of the coronal electrostatic way research with horizontal and vertical drums showed two to three times more productivity of separators with vertical drum at equal conditions. When developing structural solution of coronal electrostatic way with vertical drum the following factors were considered:

- corona electrode polarity;

- linear velocity change of drum at constant electric-field strength;

- corona discharge happens only in a heterogeneous electric field in a small area near a thin conductor (such discharge does not advance on the opposite electrode and can be viewed as a partial gas breakdown [13]); 
- corona current.

Analysis of works on charge and dynamics of mineral particles separation during coronal electrostatic way [1, 2, $4-9,11]$ shows that the mechanism of mineral particles separation in electric field is carried out by means of charged particles latching on the surface of the earthed rotating electrode.

It was assumed that forces which resulting interaction defines the behavior of the particle in coronal electrostatic way influence the particle of heat-treated hydrogen coal on the surface of receiving electrode [4]. In accordance with the second law of Newton path equation of gravitational center of a particle is as follows:

$$
m \frac{d \bar{v}}{d t}=\sum \bar{F}=\bar{F}_{\mathrm{k}}+\bar{F}_{\mathrm{T}}+\bar{F}_{\text {c.f. }}+\bar{F}_{\text {m.i.f. }}+\bar{F}_{\text {p.f. }}+\bar{F}_{\text {a.f. }}+\bar{F}_{\text {apx }}
$$

where ${ }^{-} \mathrm{Fk}$ - Coulomb force, $H ;{ }^{-} \mathrm{FT}$ - gravity force, $H ;{ }^{-}$Fc.f.- centrifugal force, $H ;{ }^{-}$Fm.i.f.- mirror imaging force, $H$; ${ }^{-}$Fa.f. - adhesive force of a particle to a receiving electrode; it is defined by forces of interaction in the area of a particle and the surface of a drum contact, $H ;{ }^{-}$Fp.f. - ponderomotive force, $H$.

There is a diagram of forces influencing the particles in a separator with the vertical drum in pic. 1. The researches showed the decrease of separators productivity at constant electric-field strength and increase of linear speed of drums. This can be explained by the fact that with the increase of centrifugal force - coarseness of confined particles and value of the layer on the drum decrease, productivity of separators decreases. There are graphs of dependence of non-conductor particles coarseness in pic. 2 (the results of theoretical and experimental researches) hanging on the surface of the receiving electrode with $1 \mathrm{~m}$ diameter on the drum revolution frequency (the data received during the test on quartz raw material classification at Kyshtymski mining and refining plant and titaniumcontaining sand preparation at Irshanski mining and refining plant [14].

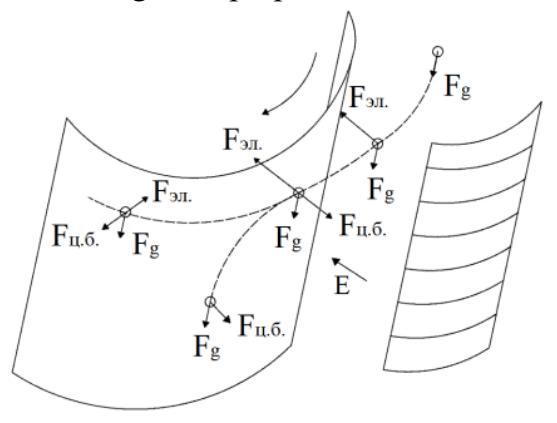

Pic. 1 Vector diagram of forces influencing the particles with vertical drum.

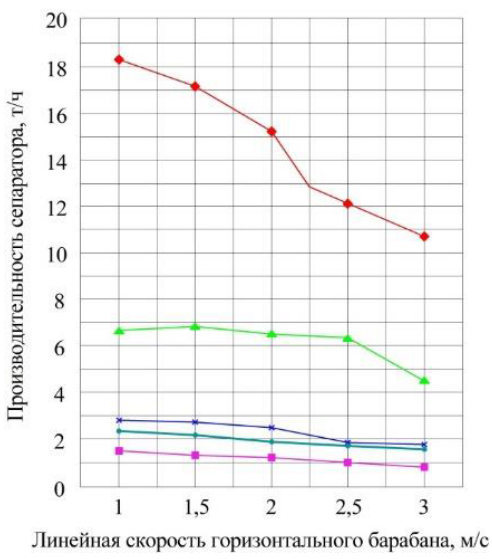

Pic. 2 Dependence of electroseparators productivity with horizontal (diameter $150-356 \mathrm{~mm}$ ) and vertical (diameter $0,5 \mathrm{~m}$ and $1,0 \mathrm{~m}$ ) receiving electrode on linear speed of drum [15].

Separator productivity $(\mathrm{t} / \mathrm{h})$

Linear speed of horizontal drum $(\mathrm{m} / \mathrm{s})$

The results of the research enable us to conclude that methods of electric separation including coronal electrostatic way of drum type, electrostatic laminose, tribo electrostatic drum and tribo adhesive drum methods are 
used for heat-treated milled hydrogen coal preparation with effective ways of its organic and mineral compound separation.

\section{Conclusion}

The necessity of technical project of heat-treated milled hydrogen coal preparation site development is due to the following facts:

- $\quad$ heat-treated hydrogen coal preparation will increase energy efficiency of enterprises up to 5\%;

- the necessity of full completing complex on high-velocity heat-treating of hydrogen coal with experimental samples of equipment on preparation with account for research processes of its effective preparation ;

- $\quad$ energy cost optimization as gas and coal mixture for preparation has been prepared energetically including the necessary heat and full delete of moisture;

- $\quad$ an understandable widening of hydrogen coal use having narrow use because of high moisture and ash content and also high concentration of volatiles which can cause inflammation of coal.

The laboratory research done for optimal coarseness, heat-treated milled hydrogen coal feeding separators and choice of the most effective technology of preparation have shown: technologies with electrostatic laminose separator and tribo adhesive separator are not effective for heat-treated milled hydrogen coal separation.

The main limitation of including coronal electrostatic way of drum type productivity is the diameter of receiving electrode and presence of one working area. To increase the productivity and effectiveness of heat-treated milled hydrogen coal separation the results of forces influencing its charged particles have been analyzed. It was stated that increase of coronal electrode diameter leads to decrease of coronal charge current. Increase of stress on coronal electrode up to $32 \mathrm{kV}$ has the biggest influence on the output. Frequency of drum revolution, decrease of drum revolution by two times (from 60 to $30 \mathrm{rev} . / \mathrm{min}$.) influences the quality of separated fractions, which leads to increase of non-conductive fraction output. Growth of coronal electrostatic way of drum type productivity is connected with facilitation from design requirements - increase of receiving electrode diameter value. Additional conditions for technological project development and effective use of electrostatic preparation methods have been set. Preparation process of pre-prepared heat-treated milled hydrogen coal should be safe, excluding risk of explosion of thin milled hot heat-treated hydrogen coal being fed. It is planned to separate heat-treated milled hydrogen coal in furnace gas environment for safe conditions during preparation process.

The work has been done in framework of federal focused program implementation "Research and Development on Priority Orientation of Science and Technology Complex Development in Russia 2014-2020", unique identifier 'Applied Research and Experimental Developments' $157914 X 0036$.

\section{References}

1. V.L. Egorov, Magnitnye, jelektricheskie i special'nye metody obogashhenija rud, (1977).

2. N.M. Karnauhov, Tehnologija dovodki kollektivnyh koncentratov s pomoshh'ju jelektricheskoj separacii, (1966).

3. I.A. Kakovskij, V.I. Revnivcev, O vlijanii sostojanija poverhnosti na process jelektricheskoj separacii mineralov s maloj jelektroprovodnost'ju. V Mezhdunarodnyj kongress po obogashheniju poleznyh iskopaemyh, (1962).

4. $\quad$ N.F. Olofinskij, V.A. Novikov, Triboadgezionnaja separacija, (1974).

5. Fraus F., Electrostatic separation of granular materials. U.S. Dept. of the interior Bureau of Mines, (1962).

6. A.I. Mamedov, Fizicheskie metody obogashhenija kamennyh rud, (1979).

7. A.I. Mesenjashin, Jelektricheskaja separacija v sil'nyh poljah, (1978).

8. I.P. Vereshhagin, G.Z. Levitov, Osnovy jelektrogazodinamiki dispersnyh sistem, (1974).

9. A.I. Angelov, B.C. Ershov, S.I. Losaberidze, M.M. Pashni, Dvizhenie zarjazhennyh chastic v jelektrostaticheskom pole koronno-jelektrostaticheskogo barabannogo separatora. Jelektronnaja obrabotka materialov, (1978). 
10. A.D. Zimon, Adgezija pyli poroshkov, (1979).

11. Je.V. Volkova, G.V. Zhus', D.V. Kuz'min, Dijelektricheskaja separacija razlichnyh polikoncentratov i materialov, (1975).

12. I.N. Plaksin, N.F. Olifinskij, Koronnaja jelektroseparacija i primenenie ee dlja obogashhenija, klassifikacii i obespylivanija, Jenergeticheskie i magnitnye metody separacii, (1965).

13. A.P. Kovalev, Jelektricheskoe obogashhenija ugol'noj pyli, (1950).

14. I.N. Plaksin, N.F. Olofinskij, O primenenii koronnyh obespylevatelej i klassifikatorov dlja obogashhenija melkih klassov poleznyh iskopaemyh, Primenenie sil jelektricheskogo polja v promyshlennosti i sel'skom hozjajstve, (1964).

15. A.I. Urvancev, Razrabotka vysokoproizvoditel'nogo barabannogo koronno-jelektrostaticheskogo separatora vertikal'nogo tipa, Cvetnye metally, (1995). 